\title{
Assessing Environmental Damage to Marine Protected Area: A Case of Perhentian Marine Park in Malaysia
}

\author{
Gazi Md. Nurul Islam ${ }^{1}$, Kusairi Mohd Noh ${ }^{1}$, Tai Shzee Yew ${ }^{2} \&$ Aswani Farhana Mohd Noh ${ }^{1}$ \\ ${ }^{1}$ Institute of Agricultural and Food Policy Studies, Universiti Putra Malaysia, Putra Infoport, Serdang 43400, \\ Selangor, Malaysia \\ ${ }^{2}$ Faculty of Economics and Management, Universiti Putra Malaysia, Serdang 43400, Selangor, Malaysia \\ Correspondence: Gazi Md. Nurul Islam, Institute of Agricultural and Food Policy Studies, Universiti Putra \\ Malaysia, Putra Infoport, 43400 Serdang, Selangor, Malaysia. Tel: 60-3-8947-1093. Email: \\ gazinuru1236@gmail.com
}

Received: May 6, 2013 Accepted: May 31, 2013 Online Published: July 15, 2013

doi:10.5539/jas.v5n8p132 URL: http://dx.doi.org/10.5539/jas.v5n8p132

\begin{abstract}
The Perhentian Island located in the East coast of Peninsular Malaysia is well-known for its rich coral reef ecosystems. Marine resources of Malaysia have been overexploited due to overfishing and tourism activities. As such no-take marine protected area (MPAs) were established in Malaysia, including Perhentian Island Marine Park to enable overexploited marine resources to recover and to conserve coral reef ecosystems. This paper examines the current level of activities causing damage to coral reef habitats in the Perhentian MPA. This study used paired comparison method to elicit the perception of local stakeholders on activities harmful to the marine habitats. The results of the analysis showed that various respondent groups had similar preference rankings on the harmful activities: littering, discarding fishing equipment, excess fishing and too many divers that cause damage to habitats in the MPA area. The findings suggest that policy makers should take cognizance of the local stakeholders' concern in planning and designing of marine protected areas in Malaysia.
\end{abstract}

Keywords: marine protected areas, tourism, overfishing, preference ranking, Peninsular Malaysia

\section{Introduction}

Marine Protected Areas (MPAs) have been suggested as an important tool for fishery management particularly in a situation where fisheries are overexploited (Alban \& Boncoeur, 2006). In Malaysia the government has undertaken MPA programmes in offshore islands in the 1980s. Malaysia has $3,600 \mathrm{~km}^{2}$ of coral reef areas which are mostly protected as marine parks. The primary objective of establishing MPAs is to protect coral reef ecosystems from fishing and other harmful activities to ensure sustainable benefits from fisheries and tourism services. In Malaysia massive tourism development has taken place over the last decades and this sector accounts for the country's second largest source of foreign exchange earnings. Several studies highlight that MPAs allow tourism activities to enhance economic benefits while enabling the recovery of overexploited marine resources (Kelleher \& Bleakley, 1995; Lauck et al., 1998; Gue'nette \& Pitcher, 1999; Russ \& Alcala, 2003; Gaylord et al., 2005).

Perhentian island is one of the coral reef islands in the east coast of Peninsular Malaysia. This island has been gazetted as a Marine Park in 1994. Various infrastructures have been developed in the island to promote tourism. In Perhentian island statistics on tourist arrivals showed an increasing trend from 51,000 in 2004 to 90,000 in 2011 (Department of Marine Park, 2012). Several studies highlight that the coral habitats in Perhentian Island has been damaged due to expansion of tourism activities (Harborne et al., 2000; Tamblyn et al., 2000). Other studies also show that Malaysian coral reefs are under medium to high levels of threat due to human activities (Burke, 2002). In Perhentian Island the live coral cover was the lowest (36.5\%) compared to other islands in Peninsular Malaysia (Reef Check Malaysia, 2011). Studies outside Malaysia showed that the increasing tourism activities especially diving and snorkeling in marine parks are the main reasons for deteriorating coral reef health (Ward, 1990; Hawkins \& Roberts, 1993; Davis \& Tisdell, 1995; Rouphael \& Inglis, 2001). In Malaysia the main reasons for coral degradation are due to the large number of tourists visiting this island, construction of land based tourism infrastructures, fishing, and pollution through waste disposal and littering (Reef Check Malaysia, 2011). 
The negative consequences of human activities to coral reefs have not been given due consideration in formulating the tourism management policy in Malaysia. Wattage et al. (2011) found that the major threat to coral reef comes from human activity which has not been addressed in the management of MPA. In this paper, we elicit community perceptions to determine the most harmful activities in Perhentian MPA that damage coral reefs using paired comparison method. The results of the study will be useful for policy makers to formulate effective planning and management of MPAs in Malaysia.

This paper is organized as follows: Section 2 describes the general characteristics of Perhentian MPA and its current management status. Section 3 presents the method of paired comparison, questionnaire and data sources. Section 4 discusses the demographic characteristics of respondents; Section 5 discusses the results, while Section 6 presents policy formulations for MPA and the final section presents the conclusions.

\section{Pulau Perhentian Marine Protected Area (PPMPA)}

The Pulau Perhentian (Perhentian Island) is located in the South China Sea, $21 \mathrm{~km}$ off the mainland of Terengganu State in the east coast of Peninsular Malaysia. The island is easily accessible by speedboat from the small fishing port of Kuala Besut on the mainland. The Perhentian Archipelago consists of two main islands, Perhentian Besar (large) and Perhentian Kecil (small), with an approximate land area of 867 and 524 hectares, respectively (Figure 1). There are also several smaller islands located close to the Perhentian Kecil island. With a diverse coral reef ecosystem and inter-tidal habitats, Pulau Perhentian is a breeding, nursing and feeding ground for numerous fish species, sea turtles and other resources. Tamblyn et al. (2005) conducted a study on coral reefs of Malaysia. They have recorded 127 types of fish species available in the marine waters surrounding Pulau Perhentian.

Marine protected area (MPA) of Pulau Perhentian was first initiated by the Department of Fisheries Malaysia (DoFM) in 1983. This island was gazetted as a Marine Park in 1994 and then established as a no-take MPA where fishing was prohibited within two nautical miles from the lowest water level in the shore. In 2004, the responsibility of MPA management was transferred from DoFM to the Marine Parks Department Malaysia (MPDM) under the Ministry of Natural Resources and Environment (MNRE). The main reason for this arrangement was to promote sustainable resource management and enhance tourism in the marine parks. However, both DoFM and MPDM belonged to the Federal government jurisdiction, while the land in the island belongs to the State Government, which decides on all land based development activities. Coordination between state and federal governments is important for sustainable resource use in the island. However, there is a dichotomy in jurisdiction between federal and state governments in Malaysia. Gopinath and Puvanesuri (2006) highlighted that the main constraint for successful marine resource management was the lack of coordination.

The government has undertaken legal protection in order to protect coral reefs from fishing in the MPA area. However the legal protection has been less effective in Perhentian island due to some reasons. Firstly, local residents who primarily rely on fishing for their livelihoods are not allowed to fish in the no-take MPA area. Although, tourism activities has provided economic opportunities for the local people, but fishers still depend on fishing in the area for their subsistence. Secondly, the government has limited capacity to control illegal fishing due to lack of enforcement of fishing rules particularly during monsoon seasons (October-February) when majority of the households participate in fishing in the MPA area.

A massive physical infrastructural development has also taken place in Pulau Perhentian over the last decade. These infrastructures consist of three jetties, a primary school, a health clinic, a police station and a post office. A generator was installed in 1994 for electricity supply; and a water treatment plant was established to provide piped water in the village. There are about 45 resorts/chalets, 19 dive shops, 40 souvenir shops, several restaurants and tea stalls employing a good number of local residents in Perhentian besar and Perhentian kecil. For the small area of Perhentian Island, the number of infrastructures was relatively high compared to other marine parks in the east coast of Peninsular Malaysia.

There is a small village called Kampung Pasir Hantu of approximately 10 ha situated in Perhentian kecil (small island). A total of 1,500 residents live in this village, and all of them are Malays. Most of the local residents were fishers prior to the establishment of Perhentian MPA. The villagers have adopted various tourism activities for better income. The main tourism activities include SCUBA diving, snorkeling, swimming and recreational fishing. These activities are carried out from March to September. During the northeast monsoon season (October to February), majority of local people participate to fish in Perhentian. All kinds of tourism activities are closed during this period. Fishers use artisanal fishing gear, namely hook and lines, traps, gill and drift nets. Trawls with relatively smaller boats operate at short distances from the coast. Fishers from other neighboring areas are also engaged in fishing in this area during this season. 


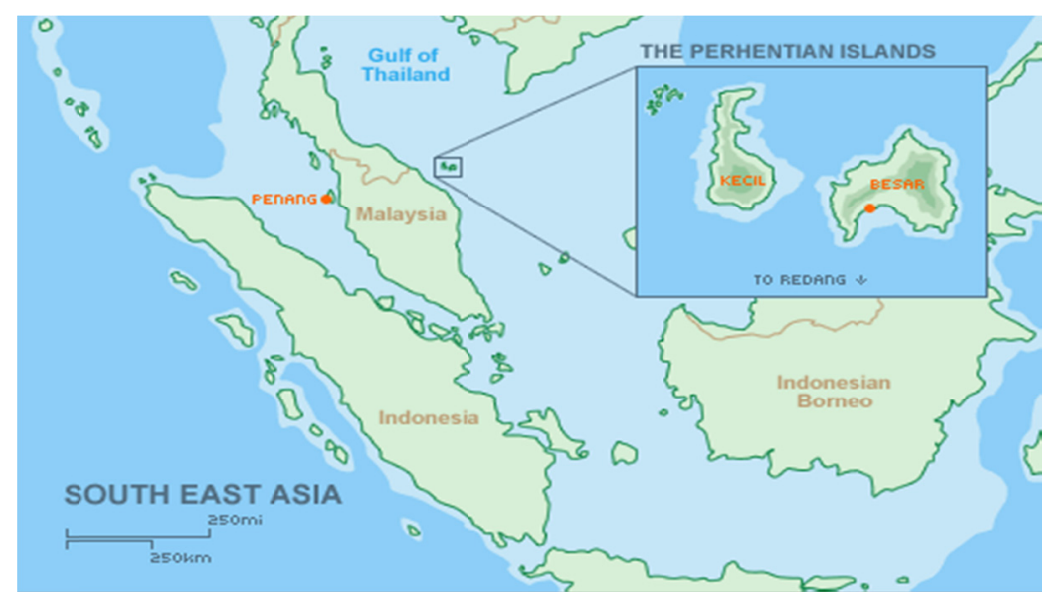

Figure 1. Perhentian island and Marine protected area

\section{Methodology}

The study adopted a primary survey approach to obtain data from the selected respondents in Perhentian island. The study investigated on how the coral reefs were being damaged in the Perhentian island MPA. This study provides information that helps to develop guidelines for management to protect and conserve coral reefs in Perhentian island.

\subsection{Paired Comparison and Damage Schedule Approach}

The study used the 'damage schedule' method developed by Chuenpagdee (1998). This method was used to elicit public judgments on identifying the most important harmful activities damaging coral reef ecosystem in Perhentian MPA. This method has been used to examine coastal environmental problems in Southern Thailand and Mexico (Chuenpagdee, 1998; Chuenpagdee et al., 2001, 2002). Quah et al. (2006) used this method to examine the environmental damage in urban coastal areas in Singapore. They found that the paired comparison method was suitable to develop a schedule that policy makers can use as a guide to reduce environment problems in coastal areas. Chuenpagdee et al. (2001) highlights that the damage schedule method is more suitable and transparent compared to other non-market resource valuation methods.

The paired comparison approach presents two scenarios at a time. The total number of possible pairs for all scenarios is $N(N-1) / 2$, where $\mathrm{N}$ is the number of scenarios. For each pair, given a specific situation, respondents were asked to choose only one scenario (either X or Y) that they considered as more important. Each selected scenario was scored and aggregated for analysis. These scores were normalized to a scale of 0 (least importance) to 100 (highest importance), and ranks were assigned based on the scale values. This assessment helps to develop a damage schedule or a predetermined schedule to revise current MPA management practices. This method guides policy makers in formulating policy design, regulatory control, management choice and payment for damages (Chuenpagdee et al., 2001).

\subsection{Questionnaire and Data Source}

The data for this study was obtained from face-to-face interview with selected respondents using structured questionnaire. Prior to field data collection, focus group discussions (FGD) and key informant surveys (KIS) were carried out to gather information about the status of coral reefs, livelihood options of local people, and tourism management in Perhentian MPA.

The questionnaire consists of three sections: Section A included household characteristics, income and employment; Section B included perception on the status of coral reefs, and information exchange among the local people; Section $\mathrm{C}$ included paired comparison questions comprising seven activity scenarios that damage coral reefs in the first set (set A) and seven community programmes in the second set (set B) giving a total number of 21 pairs for each set (Table 1). A total of 42 pairs from two sets were included in the survey booklet. A list of harmful activities for damaging coral reefs and several conservation oriented community programmes were identified from FGD and KIS. As shown in Set A of Table 1, the important harmful activities were fishing, diving, littering in the MPA. In Set B, important community programmes i.e., establishing artificial reefs, microcredit support and providing secure access to fishing and tourism activities are included. 
The study investigated the severity of harmful activities in damaging coral reefs in Perhentian. In the first set (Set A, Table 1), respondents were asked to select only one resource damage activity from each pair that they considered more "severe" in terms of the coral damage in the MPA. In the second set (Set B, Table 1), respondents were asked to choose one community programme that was likely to benefit the community and provide incentives to promote conservation.

Table 1. Coral damage activities and community programmes

\begin{tabular}{ll}
\hline Set A: Activity scenarios for coral damage \\
\hline - & Many people fishing in MPA area \\
- & Fishing in spawning area in MPA \\
- & Fishing using hook and line \\
- & Too many motorized boats used by tourists \\
- & Littering on the beach \\
- & Discarding fishing equipments \\
\hline
\end{tabular}

Set B: Community programme

- $\quad$ Establish artificial reefs for fishing

- Provide technical training to the fishers

- Provide micro credit

- $\quad$ Establish aquaculture in the sea

- Provide fishing access for subsistence

- Secured employment in tourism

- $\quad$ Reduce the MPA area

Prior to the survey, a complete household census was conducted in Perhentian. Respondents were divided into four subgroups, according to their main occupation, i.e., (1) fishers; (2) tourism workers such as boat operators, tourist guide, (3) traders/ shop owners; (4) other local residents such as government employees, housewives, retired persons. A separate respondent group or "Expert group" with experience in marine resources in this area was identified thorough discussions with various agencies in Terengganu. The respondents of this group comprised of staff from government departments, universities, and non government organizations (NGO). Quota sampling was used to select a minimum of 30 respondents from each of the sub groups. A total of 128 respondents were selected for interviews from the five sub groups. The selected respondents were informed in advance about the interview with the assistance of the village leader and local enumerators. Interviews were mostly conducted in late afternoon as most of them were available during this time. The survey booklet was completed through face to face interview. A map of the island, a set of pictures and fact sheets describing the status of coral reefs and fisheries resource conditions in Perhentian were provided to each respondent during the survey. Each survey took around 45 minutes to complete.

\section{Respondents Characteristics and Their Perceptions Towards Resources in MPA}

\subsection{Demographic Characteristics}

The study interviewed a total of 128 respondents of which 107 were males, while 21 were females. Among the five subgroups, tourism workers and traders were relatively younger (average age below 40 years) compared to fishers (48 years), experts (45 years) and others (48 years). The average household size was 6, ranged from 3 to 9 people. Majority of the tourism workers and traders had attained secondary education, while about half of the fishers had attained primary education. 
Table 2. Respondents perception on resource condition in MPA (\%)

\begin{tabular}{llllll}
\hline Resource & Declining & Increasing & Same & Don't know & All \\
\hline Beach & $42.9(45)$ & $40.0(42)$ & $17.1(18)$ & - & $100(105)$ \\
Coral Reef & $49.7(53)$ & $37.7(39)$ & $9.7(10)$ & $2.9(3)$ & $100(105)$ \\
Fish biomass & $48.5(51)$ & $43.8(46)$ & $4.8(5)$ & $2.9(3)$ & $100(105)$
\end{tabular}

Note: number of respondents is shown in parentheses; the expert group is not included here.

About half of the respondents informed that the condition of coral reefs and fish biomass has severely deteriorated in Perhentian Island MPA (Table 2). However, the deterioration is less severe in sandy beaches. The evidence suggests that the declining of coral reefs was due to the increasing number of tourist activities in this island.

Table 3. Source of information exchange in Perhentian island

\begin{tabular}{lll}
\hline Agency/person & Number of respondents & $\%$ \\
\hline Village Leader & 35 & 33.7 \\
Department of Fisheries & 34 & 33.2 \\
Department of Marine Park & 84 & 80.8 \\
Friends/relatives & 46 & 44.2 \\
\hline
\end{tabular}

The study shows that the majority of respondents (81\%) had access to information regarding MPA management from the local marine park office. About $44 \%$ of respondents reported that they obtained information from their friends and relatives. The results indicate that there is a lack of communication support from fisheries agencies in the marine park.

Table 4. Kendal Tau rank-order correlation coefficients

\begin{tabular}{llllll}
\hline Group & Fishers & $\begin{array}{c}\text { Tourism } \\
\text { workers }\end{array}$ & Traders & Others & Experts \\
\hline Resource damage activities & & & \\
Fishers & 1.000 & & & \\
Tourism & $0.964 * *$ & 1.000 & & & \\
Traders & $0.964^{* *}$ & $1.000^{* *}$ & 1.000 & & \\
Others & $0.929^{* *}$ & $0.964^{* *}$ & $0.964^{* *}$ & 1.000 & \\
Experts & $0.752^{*}$ & $0.857^{* *}$ & $0.857^{* *}$ & $0.786^{*}$ & 1.000 \\
Community Programmes & & & & \\
Fishers & 1.000 & & & & \\
Tourism & $0.881^{* *}$ & 1.000 & & & \\
Traders & $0.821 * *$ & $0.992^{* *}$ & 1.000 & & \\
Others & 0.672 & $0.870^{* *}$ & $0.871^{* *}$ & 1.000 & \\
Experts & $0.909 * *$ & $0.988^{* *}$ & $0.975^{* *}$ & $0.821^{* *}$ & 1.000 \\
\hline
\end{tabular}

** Denotes significant correlation at $p=0.01$.

*Denotes significant correlation at $p=0.05$.

\section{Paired Comparison Analysis Results: Community Judgment about MPA}

Individual respondents' preference scores were obtained through paired comparison survey. These scores were aggregated for each sub-group (fishers, tourism workers, traders, experts, and others) and ranks were assigned to 
these aggregated scores. The Kendall's Tau rank-order correlation analysis was used to test if there was an agreement in the rankings provided by the respondent groups. As shown in Table 4, the rankings for the five sub groups were close-to-perfect correlations. All the Kendall's Tau rank-order correlation coefficients were significantly less than the $p$-value of 0.05 . This indicates that the level of agreement was highly correlated among respondent groups, in both resource damage activities and community programmes.

Table 5 presents the aggregated performance score for the activity scenarios and community programmes based on the paired comparison for each of the five subgroups. The score values were normalized (0 to 100) and a ranking was assigned to these normalized scores in order to test for an agreement between the respondent groups using Kendall coefficient of agreement $(u)$ (Siegel and Castellan, 1988). This test measures the degree of similarity of rank ordering provided by a single respondent group. The value of $u$ is one when the level of agreement is full among individuals. The chi-square goodness-of-fit test was also used to test the significance of agreement for a large sample size. The chi-square goodness-of-fit tests for Kendall coefficient of agreement (u) were all less than the critical $p$ - value of 0.001 level of probability, thus rejecting the null hypothesis that significant agreement exists among the respondents in each subgroup (Table 5).

Littering and discarded fishing equipment were found to be the most harmful activities to coral reefs. The range of the scale value between these two activities was relatively large for the expert group (58 to 93) but the range was smaller for the other four groups (Table 5). The results of the study suggest that the expert group is not fully aware of the problem of discarding fishing materials, although they are concerned about fishing in spawning area (scale value of 72).

Table 5. Aggregated performance scores for activities and programmes by groups

\begin{tabular}{lcclll}
\hline $\begin{array}{l}\text { Damage activity and community } \\
\text { programmes }\end{array}$ & Fishers & Tourism & Traders & Others & Experts \\
\hline Resource damage activities & & & & & \\
Littering on the shore & $75(1)$ & $85(1)$ & $83(1)$ & $87(2)$ & $93(1)$ \\
Discarded fishing equipments & $72(2)$ & $81(2)$ & $73(2)$ & $88(1)$ & $58(3)$ \\
Fishing in spawning area & $65(3)$ & $60(3)$ & $55(3)$ & $45(3)$ & $72(2)$ \\
Too many people fishing & $32(5)$ & $48(4)$ & $44(4)$ & $43(4)$ & $55(4)$ \\
Diving in the coral reef area & $58(4)$ & $30(5)$ & $29(5)$ & $29(5)$ & $20(7)$ \\
Too many motorized boats & $19(6)$ & $14(6)$ & $23(6)$ & $24(6)$ & $29(5)$ \\
Fishing using hooks and line & $12(7)$ & $13(7)$ & $16(7)$ & $18(7)$ & $19(6)$ \\
Number of respondents $k$ & 30 & 32 & 29 & 14 & 23 \\
Kendall coefficient of agreement $u$ & 0.448 & 0.496 & 0.352 & 0.304 & 0.315 \\
Chi-square* & 293.6 & 343.9 & 227.8 & 104.0 & 166.5 \\
Community programmes & & & & & \\
Establish artificial reefs & $77(1)$ & $71(1)$ & $62(1)$ & $61(3)$ & $83(1)$ \\
Provide technical training to fishers & $59(2)$ & $70(2)$ & $61(2)$ & $85(2)$ & $71(2)$ \\
Provide micro credit to fishers & $54(3)$ & $68(3)$ & $59(3)$ & $76(1)$ & $64(3)$ \\
Establish aquaculture in the sea & $52(4)$ & $48(4)$ & $51(4)$ & $43(5)$ & $46(4)$ \\
Provide fishing access & $31(6)$ & $31(5)$ & $34(6)$ & $36(6)$ & $36(6)$ \\
Building residence for tourists & $31(6)$ & $39(5)$ & $42(5)$ & $48(4)$ & $43(5)$ \\
Reduce fishing restriction & $44(5)$ & $22(7)$ & $27(7)$ & $23(7)$ & $23(7)$ \\
Number of respondents & 30 & 32 & 29 & 14 & 23 \\
Kendall coefficient of agreement $u$ & 0.370 & 0.469 & 0.551 & 0.314 & 0.224 \\
Chi-square* & 168.8 & 208.0 & 247.2 & 138.6 & 153.2 \\
\hline
\end{tabular}

*significant agreement at $p<0.001$.

Note: Figures in parenthesis show rankings. 
In the community programmes, it was found that fishers mostly preferred the activities that might increase fish productivity (scale value of 77) for example, increase fish biomass through artificial reef establishment, while other groups (women and traders) preferred micro credit programme (Table 5). Local people can use micro credit to invest in various self employment activities to increase their income. Thus, dependency on marine resources for livelihoods may be reduced.

The study found that both the resource dependent group and expert group had similar concerns about harmful activities to coral reefs. The respondent groups preferred similar community programmes in the Perhentian MPA. Therefore, it was possible to aggregate the scores of all respondents into one scale for damaging activities and another scale for community programmes (Table 6). Among the activities, littering was found to be the most damaging activity (scale value of 85), followed by discarded fishing equipments (scale value of 74).

Table 6. Aggregated performance scores

\begin{tabular}{|c|c|c|c|}
\hline Coral Damage Activities & All groups & Community Programme & All groups \\
\hline Littering on the shore & $85(1)$ & $\begin{array}{l}\text { Creating more artificial reefs in the } \\
\text { MPA }\end{array}$ & $71(1)$ \\
\hline Discarded fishing equipments & $74(2)$ & Build a centre for technical training & $69(2)$ \\
\hline Fishing in spawning area & $59(3)$ & Provide micro credit support & $64(3)$ \\
\hline Too many people fishing & $44(4)$ & Promote small scale aquaculture & $48(4)$ \\
\hline $\begin{array}{l}\text { Diving in the shallow part of } \\
\text { MPA }\end{array}$ & $33(5)$ & Build hotels/chalet for tourists & $41(5)$ \\
\hline Too many motorized boats & $22(6)$ & Provide fishing access for local fishers & $34(6)$ \\
\hline Fishing using hooks and line & $16(7)$ & Reducing the restricted area of MPA & $28(7)$ \\
\hline
\end{tabular}

\section{Policy Implications for MPA Management}

The results of the study showed that all the sub groups of respondents (fishers, tourism workers, traders, experts and others) were concerned about littering and fishing activities damaging coral reefs in Perhentian MPA. The respondents had suggested the most damaging activities and the least damaging activities to coral reefs. Based on the community judgment it is possible to develop predetermined damage schedule that can be used as a guide to adjust the MPA management policy. Policy makers can impose sanctions as well as incentives for the activities in the MPA for sustainable use of coral reef ecosystems in Perhentian island.

The existing policy on tourism management does not effectively protect the coral reefs in Perhentian Island. The increasing number of tourists visiting this marine park poses pressure on the island. The beach and coral reefs are excessively used by the visitors undertaking various tourism activities. The current use of coral reefs should be reduced and the number of tourists should be regulated based on the carrying capacity of the coral reef habitat.

The increasing number of chalets and jetties negatively affects coral reef ecosystems. Development agencies should assess the environmental impact of infrastructures on the environment of the MPA. Studies have highlighted that small island destinations are the most vulnerable to environmental impacts from tourism activities (Gossling, 2003). Salmond (2010) found that land based development activities had created significant damage to the coral reef habitats in Perhentian Island. The environmental consequences of tourism in the marine parks should be addressed in the design and implementation of marine policies in Malaysia. There is a need to conduct Environmental Impact Assessment (EIA) to assess the possible risk and threats from these activities on the resources in the MPA.

Although fishing is totally prohibited in the MPA area in Perhentian, there is clear evidence that the majority of the local fishers are involved in fishing particularly in the monsoon season. Fishing nets are entangled with coral reefs which hinder diving activities as well as pollute the coral reef habitats. Prior to imposing no take MPA, local fishers were not adequately consulted. Participation of local fishers in the MPA management is essential since the government has limited capacity to enforce management regulations. Effective coordination between the important agencies such as the Department of Fisheries and Department of Maine Parks is required to ensure fishers cooperation and support to protect coral reefs in the MPA. 
In Malaysia the state government has authority for all land management in the marine park islands, while the Marine Park Department Malaysia (MPDM) is responsible for the management of MPAs water area up to two nautical miles surrounding the island. These overlapping jurisdictions of legislation between state and federal governments are the major constraint for preserving coral reef resources in Perhentian MPA. The top down management system in Malaysia generally excludes local people's participation in the management of coastal marine resources. There is also lack of coordination between the federal and state governments.

The government should restrict land development activities, particularly in the land scarce small island such as Perhentian. Both state and federal agencies should give priority to involve the community which is a key factor in ensuring the success of a marine protected area (White, 1986; Kaza, 1988; Kenchington, 1988; Cinner, 2005). Sumaila et al. (2000) highlighted that successful implementation of MPA management is difficult without consultation with the local people.

The results of the study revealed that local people are aware of the damaging activities in the Perhentian island. The government should provide public awareness and education programs to the community. These programmes help the community to understand the importance of protecting coral reef ecosystems in the marine parks. Besides the community, marine park staff, tour operators, dive operators should also be adequately trained to reduce harmful activities and ensure sustainable management of MPAs in Malaysia.

\section{Conclusion}

The results of the study provide scales of various damaging activities which can be used to construct a damage schedule to be used as a policy guide for protecting coral reefs in Perhentian MPA. This schedule is based on the community agreement on how coral reef ecosystems are negatively affected. The schedule can impose more strict sanctions on the severe harmful activities and impose less strict sanctions on the less harmful activities. The study reveals that the severe damaging activities are due to the overwhelming pressure from tourism activities on the small island. The current tourism policy does not effectively protect the coral reef ecosystems. The government can reduce the use of coral based recreational activities such as diving and snorkelling in Perhentian MPA.

Sustainability of tourism in this island depends directly on the health of coral reefs. Excess fishing is also harmful to the coral reefs; however, fishers primarily depend on fishing for their livelihoods. It was expected that fishers would shift to tourism activities to compensate their loss of income from fishing which has been restricted in the MPA area. The fisher respondents had suggested implementing artificial reefs surrounding the MPA area where they can fish. Such incentives may foster conservation of coral reef habitats and achieve long term benefits from MPA. Credit support can also promote local people who can invest in other non fishing income opportunities. The community development programmes suggested by the local people is important for policy makers to formulate conservation based planning and management of the marine parks in order to reduce exploitation of fisheries and coral reefs.

Community awareness towards protecting coral reefs is vital in Perhentian as this resource is the dominant contributor to the livelihoods of local residents. Various community awareness programmes should be conducted at the local level to inform the users about the importance of protecting and conserving coral reefs for their sustainable benefits. These awareness programmes will help to improve knowledge among the users. The most important concerns about coral reef damage need to be discussed between the users and the government authority. Thus a consensus can be made through such discussions and help formulate sustainable management of the coral reef resources in the MPA in Perhentian island.

\section{Acknowledgements}

The authors are grateful for financial support provided by the Research University Grants (RUGS), Universiti Putra Malaysia. The authors gratefully acknowledge the field support provided by the SEAFDEC/MFRDMD team in Terengganu. The authors like to thank Dr. Rajan from Universiti Putra Malaysia to provide English language support in preparing the manuscript. We thank IASC International Conference participants at Foundation for Ecological Security, Hyderabad, India. Lastly, we are grateful to all the respondents participated in our study.

\section{References}

Alban, F., \& Boncoeur, J. (2006). Assessing the impact of marine protected areas on recreational uses of a marine ecosystem: the case of scuba diving. In Proceedings of the Thirteenth Biennial Conference of the International Institute of Fisheries Economics \& Trade, July 11-14, 2006, Portsmouth, UK: Rebuilding Fisheries in an Uncertain Environment. Compiled by Ann L. Shriver. International Institute of Fisheries Economics \& Trade, Corvallis, Oregon, USA, 2006. CD ROM. 
Burke, L., Selig L., \& Spalding, M. (2002). Reefs at Risk in Southeast Asia, World Resources Institute. Washington DC, USA. Retrieved from: http://www.wri.org/publication/reefs-risk-southeast-asia

Chuenpagdee, R. (1998). Damage schedules for Thai coastal areas: An alternative approach to assessing environmental values, EEPSEA Research Report Series, August $1998 . \quad$ Singapore. http://dx.doi.org/10.1080/089207502753504706

Chuenpagdee, R., Fraga, J., \& Euan, J. (2002). Community’s perspective toward marine reserve: a case study of San Felipe, Yucatan, Mexico. Coastal Management, 30, 183-91. http://dx.doi.org/10.2307/3146976

Chuenpagdee, R., Knetsch, J. L., \& Brown, T. C. (2001). Environmental damage schedules: Community judgments of importance and assessments of losses. Land Economics, 77(1), 1-11.

Cinner, J. (2005). Socioeconomic factors influencing customary marine tenure in the Indo-Pacific. Ecology and Society, 10(1), 1-14.

Davis, D., \& Tisdell, C. (1995). Recreational SCUBA diving and carrying capacity in marine protected areas. Ocean \& Coastal Management, 26(1), 19-40. http://dx.doi.org/10.1016/0964-5691(95)00004-L

Department of Marine Park, Visitors in Perhentian Island (unpublished data) (2012). Department of Marine park office, Terengganu, Malaysia.

Gaylord, B., Gaines, S. D., Siegel, D. A., \& Carr, M. H. (2005). Marine reserves exploit population structure and life history in potentially improving fishery yields. Ecological Applications, 15, 2180-2191. http://dx.doi.org/10.1890/04-1810

Gopinath, N., \& Puvanesuri, S. S. (2006). Marine Capture Fisheries. Aquatic Ecosystem Health \& Management, 9(2), 215-226. http://dx.doi.org/10.1080/14634980600721086

Gossling, S. (2003). Tourism and Development in Tropical Islands: Political Ecology Perspectives. Cheltenham, UK: Edward Elgar Publishing Ltd.

Gue'nette, S., \& Pitcher, T. J. (1999). An age-structured model showing the benefits of marine reserves against overexploitation. Fisheries Research, 39, 295-303. http://dx.doi.org/10.1016/S0165-7836(98)00173-8

Harborne, A., Fenner, D., Bames, A., Beger, M., Harding, S., \& Roxburgh, T. (2000). Status report on coral reefs of the East Coast of Peninsular Malaysia, Kuala Lumpur. Report prepared to Department of Fisheries, Malaysia. $\quad$ Retrieved from http://www.dmpm.nre.gov.my/files/Status\%20Report\%20on\%20The\%20Reefs \%20of\%20The\%20East $\% 20$ Coast $\% 20$ of\%20Peninsular\%20Malaysia.pdf

Hawkins, J. P., \& Roberts, C. M. (1993). Effects of recreational scuba diving on coral reefs: trampling on reef-flat communities. J. Appl. Ecology, 30, 25-30. http://dx.doi.org/10.2307/2404267

Kaza, S. (1988). Community involvement in marine protected areas. Oceans, 31(1), 75-81.

Kelleher, G., Bleakley, C., \& Wells, S. (1995). A global representative system of marine protected areas, Washingtion, DC: World Bank. Retrieved from: http://books.google.com.my/books?id=J2TwAAAAMAAJ

Kenchington, R. A. (1988). Managing reefs and inter-reef environments and resources for sustained exploitive, extractive and recreational uses, Proceedings of the 6th International Coral Reef Symposium, Australia.

Lauck, T., Clark, C. Mangel, M., \& Munro, G. (1998). Implementing the precautionary principle in fisheries management through marine protected areas. Ecological Applications, 8(1), $72-78$. http://dx.doi.org/10.2307/2641364

Quah, E., Choa, E., \& Tan, K. C. (2006). Use of Damage Schedules in Environmental Valuation: the Case of Urban Singapore. Applied Economics, 38, 1501-1512. http://dx.doi.org/10.1080/00036840500399842

Reef Check Malaysia. (2011). Status of Coral Reefs in Malaysia. Retrieved from www.reefcheck.org.my

Rouphael, A., \& Inglis, G. (2001). Take only photographs and leave only footprints? An experimental study of the impacts of underwater photographers on coral reef dive sites. Biological Conservation, 100(3), 281-287. http://dx.doi.org/10.1016/S0006-3207(01)00032-5

Russ, G. R., \& Alcala, A. C. (2003). Marine reserves: rates and patterns of recovery and decline of predatory fish 1983-2000. Ecological Applications, 13, 1553-1565. http://dx.doi.org/10.1890/01-5341

Salmond, L. J. (2010). The Social Relations of Tourism on the Perhentian Islamds, Doctoral Dissertations. University of Kentucky, Retrieved from http://uknowledge.uky.edu/gradschool_diss/2 
Siegel, S., \& Castellan, N. J. (1988). Nonparametric Statistics for the Behavioral Sciences (2nd ed.). New York: McGraw-Hill.

Sumaila, U. R., Guennette, S., Alder, J., \& Chuenpagdee, R. (2000). Addressing Ecosystem Effects of Fishing Using Marine Protected Areas, ICES J. Marine Science, 57, 752-760. http://dx.doi.org/10.1006/jmsc.2000.0732

Tamblyn, A., Turner, C., O’Malley, R., Weaver, N., Hughes, T., Hardingham, S., \& Roberts, H. (2005). Malaysia Tropical Forest Conservation Project, Report of the Perhentian Island, Coral Cay Conservation Ltd. London, SW19 2JG, UK. Retrieved from www.coralcay.org/app/.../malaysia_t_2005_perhentian.5pdf.pdf

Ward, F. (1990). Florida's coral reefs are imperiled. National Geographic, 115-32.

Wattage, P., Glenn, H., Mardle, S., Van Rensburg, T., Grehan, A., \& Foley, N. (2011) Economic value of conserving deep-sea corals in Irish waters: A Choice experiment study on marine protected areas. Fisheries Research, 107, 59-67. http://dx.doi.org/10.1016/j.fishres.2010.10.007

White, A. T. (1986). Marine reserves: how effective as management strategies for Philippines, Indonesian and Malaysian coral reef environments? Ocean Management, 10, 137-159. http://dx.doi.org/10.1016/0302-184X(86)90019-3

\section{Copyrights}

Copyright for this article is retained by the author(s), with first publication rights granted to the journal.

This is an open-access article distributed under the terms and conditions of the Creative Commons Attribution license (http://creativecommons.org/licenses/by/3.0/). 